\title{
Dystrophy, Abiotrophy, Amyotrophy
}

\author{
J.M.S. Pearce \\ Emeritus Consultant Neurologist, Department of Neurology, Hull Royal Infirmary, Hull, UK
}

'Dystrophy' is a common term, found in psoriatic nail dystrophy, macular dystrophy, and corneal dystrophy. In neurology, there are a few familiar examples. Many refer to the dystrophic process or to a pathogenetic mechanism; others refer to diseases, such as progressive muscular dystrophy, dystrophia myotonica, the badly named syndrome of reflex sympathetic dystrophy, or to eponymous disorders such as Becker's Dystrophy, Cogan's dystrophy.

Gowers [1] may have invented the term 'abiotrophy', which is only subtly different from dystrophy; it is also degenerative but suggests a loss of vitality and a degeneration of cells and tissues. Gowers used the word abiotrophy in his visual studies. But, confusingly, he also speaks of loss of vitality in pseudohypertrophic paralysis (Duchenne dystrophy).

Dystrophy comes to us from Latin dys + trophia, from the Greek dus (bad or disordered) + trofia (nourishment).
Dystrophic is the adjective pertaining to, or characterized by dystrophy. It applies to any degenerative disorder resulting from inadequate nutrition, or more specifically to muscular dystrophy. Amyotrophy is another closely related word, meaning literally lack of muscle growth or nourishment, but often used imprecisely or loosely to mean acquired muscle wasting, e.g. neuralgic amyotrophy, diabetic amyotrophy.

The word dystrophy is not apparent in Duchenne's work [2], nor is it used in the text or index of Gowers' Manual, first edition (1886) [3]. Gowers mentions it in the second edition (1891; p. 503), but once only - in a chapter subtitle: 'Idiopathic Muscular Atrophy. Muscular Dystrophy'. He attributes the word dystrophy to Erb. In1891, Erb, former pupil of Friedreich of Heidelberg, suggested muscular dystrophies were a primary degeneration of muscle and coined the term 'dystrophia muscularis progressiva' [4].

\section{References}

1 Gowers WR: Subjective Sensations of Sight and Sound, Abiotrophy, and Other Lectures. London, Churchill, 1907, pp 18-41.

2 Duchenne GBA: Selection from the Clinical Works of Dr. Duchenne (de Boulogne). Translated and edited by GV Poore. London, New Sydenham Society, 1883, pp 173ff.
3 Gowers WR: A Manual of Disease of the Nervous System. London, Churchill, 1886, vol 1, pp 391-394.

4 Erb W: Dystrophia muscularis progressiva. Klinische und pathologisch-anatomische Studien. Dtsch Z Nervenheilkd 1891;1:173-261.

\section{KARGER}

Fax +4161306 1234 E-Mail karger@karger.ch www.karger.com
(C) 2005 S. Karger AG, Basel 0014-3022/05/0541-0054\$22.00/0

Accessible online at:

www.karger.com/ene
J.M.S. Pearce

304 Beverley Road

Anlaby, East Yorks HU10 7BG (UK) 